\title{
High-carbohydrate and high-protein diets alter liver and brain insulin receptors in rats
}

\author{
P. Maćkowiak, D. Ladoń, L. Nogowski and K.W. Nowak
}

Department of Animal Physiology and Biochemistry, Agricultural University of Poznan,, Wolyńska 35, 60-637 Poznań, Poland

(Received 8 September 1993; accepted 28 September 1993)

\section{ABSTRACT}

Insulin receptors of liver and brain plasma membranes were investigated in rats kept on standard (S), high-carbohydrate (HC) and high-protein (HP) diets. Both liver and brain show similar tendency to reduce number of high affinity receptors and their affinity to the hormone in rats fed a HP diet. After a HC diet the effects seem to be opposite. Animals show nearly the same number of receptors as in the control group but the affinity of insulin binding to liver - but not brain -- plasma membranes is enhanced.

KEY WORDS: insulin receptors, rat, liver, brain, diet

\section{INTRODUCTION}

Food consumed by animals is not only a source of components used by tissues for energy or as a building material, but also regulates secretion of many substances, including insulin, which is one of the most important anabolic hormones. Insulin mediates several important functions involved in cellular metabolism of proteins (Lewis et al., 1992), lipids (Susini et al., 1979) and carbohydrates (Lawrence et al., 1976). Action of insulin is regulated by the rate of its secretion and it is well known that fasting lowers insulin concentration in blood and sugars or amino acids evoke enhancement of its secretion from pancreas (Maćkowiak, 1990; Steffens et al., 1984). However, effects caused by insulin in target tissues depend not only on its level in blood but a major role plays interaction of the hormone with membrane receptors, which transmit signals to the intracellular space. Some aspects of the food influence on insulin receptors were investigated by Okamoto et al. (1992) on rats fed a lipid-rich diet, and by Dardevet et al. (1991) who carried out experiments on liver of growing rats 
after a protein-rich diet. On the other hand, changes of receptors were noticed also after fasting (Almira and Reddy, 1979).

This study was undertaken in order to put more light on the linkage of sugar and protein content in a fodder with a number and affinity of insulin receptors which can be regarded as markers of tissue activity. On the other hand, only scanty data on the brain insulin receptors are available and lots of questions concerning their role and action need further explanations (Unger et al., 1991a, b).

\section{MATERIAL AND METHODS}

Fifteen adult male Wistar rats, weighing about $360 \mathrm{~g}$, were housed individually in standard room conditions with free access to food and water. Control group (five animals) was kept on Murigran diet (commercial food produced by Bacutil-Poland, in \%: wheat bran -10 , ground corn -17.5 , ground wheat -20 , ground oat -15 , fish meal -8 , skim - milk powder -12 , casein -5.5 , yeast powder -5 , dried green forage -5 , mineral and vitamin additives -2 ; metabolizable energy $-12.8 \mathrm{MJ} / \mathrm{kg}$ of dry matter, crude protein $-24 \%$, crude fat $-3.7 \%$ ). This diet was supplemented with fish meal $(60 \%$ crude protein, $7.5 \%$ crude fat $)$ to reach final concentration of $40 \%$ protein (high-protein group, five animals) or with $25 \%$ of chemically pure starch (high-carbohydrate group, five animals). After two weeks of feeding experimental diets, rats were decapitated and tissues were taken for analyses.

Brain and liver plasma membranes were prepared according to the method of Havrankova et al. (1978). Briefly, tissues were homogenized in $\mathrm{NaHCO}_{3}$ $(1 \mathrm{mmol} / \mathrm{l})$ and centrifuged at $600 \mathrm{~g}$ for $30 \mathrm{~min}$. Obtained supernatants were centrifuged at $20000 \mathrm{~g}$ for $30 \mathrm{~min}$. and pellets were resuspended in $1 \mathrm{mmol} / 1$ $\mathrm{NaHCO}_{3}$; this step was next repeated and the final suspensions, after protein determination by a method of Lowry et al. (1951), were centrifuged once more in the same manner. Obtained pellets of membranes were resuspended in the incubation buffer (Tris $40 \mathrm{mmol} / 1, \mathrm{pH} 7.4$, containing $0.2 \mathrm{~g} / \mathrm{l} \mathrm{BSA}$ ). All procedures mentioned above were carried out at $4^{\circ} \mathrm{C}$.

In order to investigate insulin binding, $80 \mathrm{pg}$ of ${ }^{125} \mathrm{I}$-labelled porcine hormone (OPiDI Świerk, Poland) and varying amounts of unlabelled insulin $(0.02-700 \mathrm{nmol} / 1)$ were incubated $\left(16 \mathrm{~h}\right.$ at $\left.4^{\circ} \mathrm{C}\right)$ with previously prepared membranes (final concentration of proteins $-0.5 \mathrm{mg} / \mathrm{ml}$ for liver and $1.0 \mathrm{mg} / \mathrm{mol}$ for brain plasma membranes). The nonspecific binding of ${ }^{125} \mathrm{I}$-insulin was determined at $10 \mu \mathrm{mol} / 1$ of unlabelled insulin and subsequently subtracted from each value. Finally, after total radioactivity had been measured, vials were centrifuged at $20000 \mathrm{~g},\left(4^{\circ} \mathrm{C}, 8 \mathrm{~min}\right)$ and obtained pellets were used for counting.

Dissociation rate constant $\left(\mathrm{K}_{d}\right)$ and binding capacities $\left(\mathrm{B}_{\max }\right)$ for insulin were determined by the Scatchard's analysis method (Scatchard, 1949) using the 
LIGAND-PC v.3.1 computer program (Munson and Rodbard, 1980). Binding potency of insulin was calculated as $\mathrm{IC}_{50}$ using the ALLFIT-PC v. 2.7 computer program (De Lean et al., 1978).

The results were interpreted according to one-way analysis of variance. Significance of differences between groups was calculated using multiple range test.
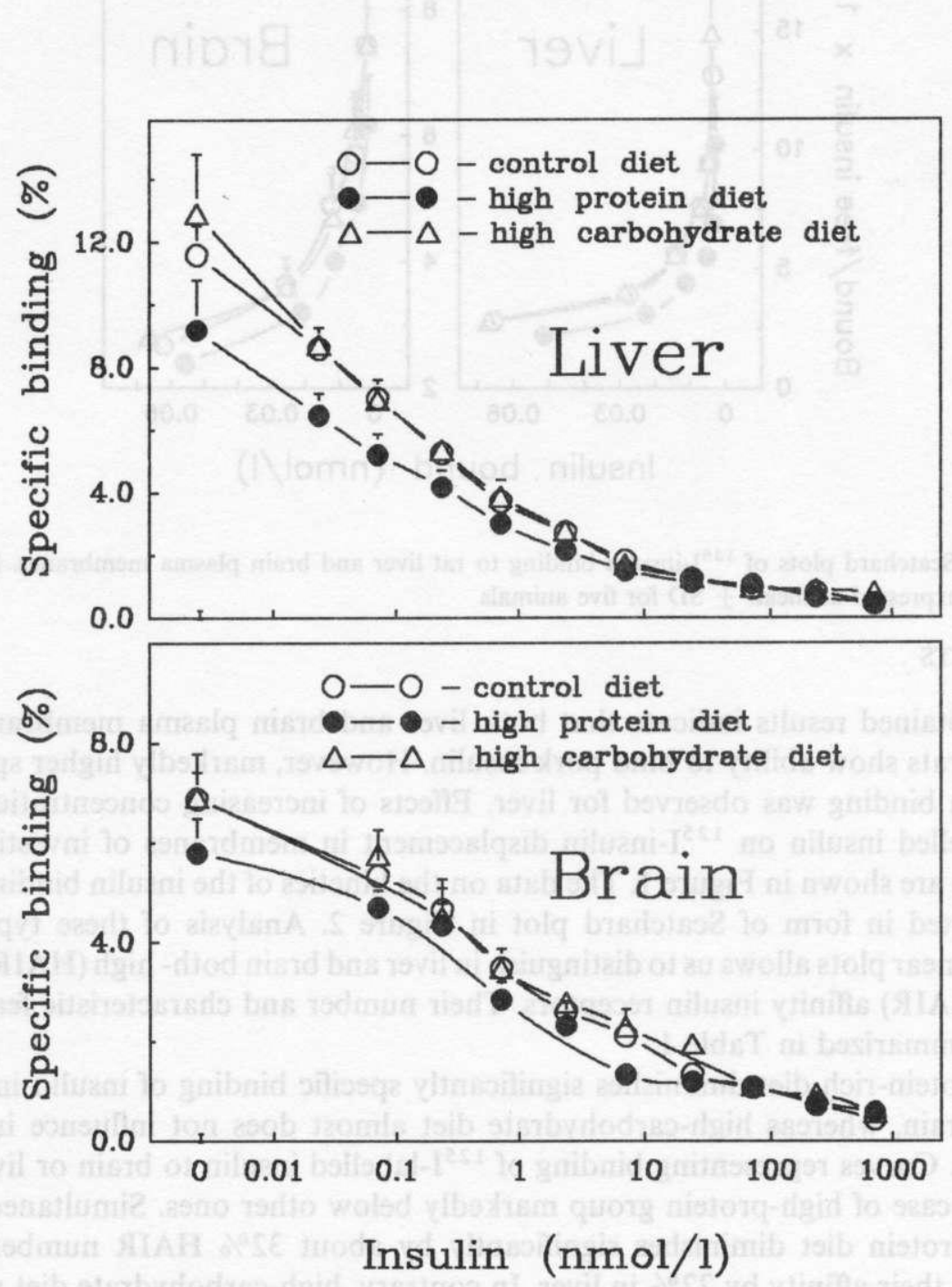

Fig. 1. Displacement of ${ }^{125} \mathrm{I}$-insulin binding to rat liver and brain membranes by unlabelled pork insulin. Results expressed as mean \pm SD for five animals 


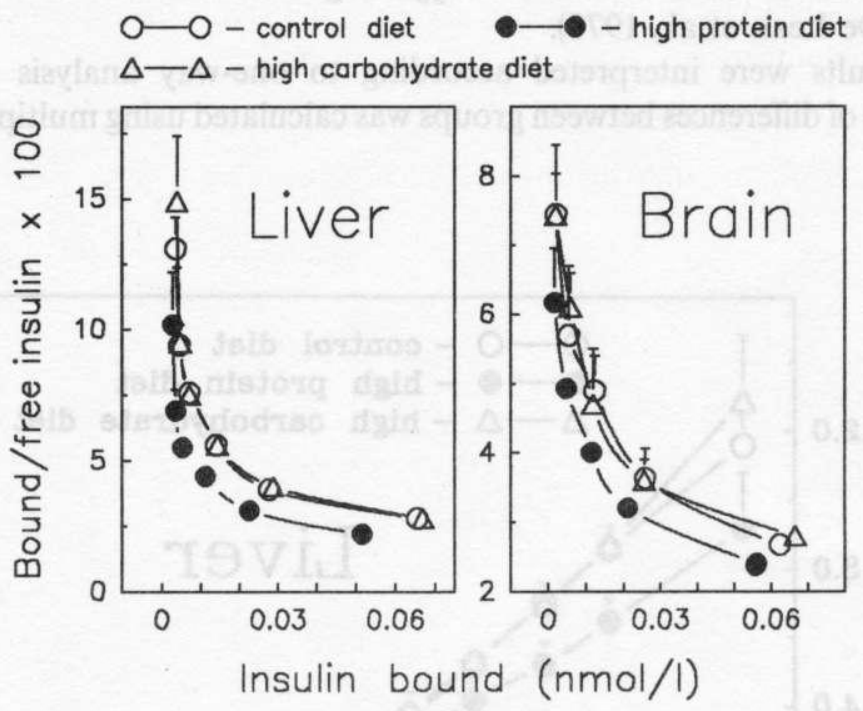

Fig. 2. Scatchard plots of ${ }^{125} \mathrm{I}$-insulin binding to rat liver and brain plasma membranes. Results expressed as mean \pm SD for five animals

\section{RESULTS}

Obtained results indicate that both liver and brain plasma membranes in adult rats show ability to bind pork insulin. However, markedly higher specific insulin binding was observed for liver. Effects of increasing concentrations of unlabelled insulin on ${ }^{125} \mathrm{I}$-insulin displacement in membranes of investigated tissues are shown in Figure 1. The data on the kinetics of the insulin binding are presented in form of Scatchard plot in Figure 2. Analysis of these typically curvilinear plots allows us to distinguish in liver and brain both- high (HAIR) and low (LAIR) affinity insulin receptors. Their number and characteristic features are summarized in Table 1.

Protein-rich diet diminishes significantly specific binding of insulin in liver and brain, whereas high-carbohydrate diet almost does not influence insulin action. Curves representing binding of ${ }^{125} \mathrm{I}$-labelled insulin to brain or liver lie in the case of high-protein group markedly below other ones. Simultaneously, high-protein diet diminishes significantly by about $32 \%$ HAIR number and lowers their affinity by $22 \%$ in liver. In contrary, high-carbohydrate diet which practically does not change HAIR number, elevates their affinity by $43 \%$. That effect is extremely visible while high-protein and high-carbohydrate groups are compared. In that case affinity of receptors in the last group is almost twice 
higher. In brain diets cause similar changes. Animals kept on a high-protein food have reduced specific binding by $16 \%$ and lowered amount of HAIR by $21 \%$. Also, affinity of HAIR is diminished by $25 \%$, whereas after high-carbohydrate food it is unchanged.

TABLE 1

The effect of high protein (HP) and high carbohydrate (HC) diets on insulin receptors in liver and brain membranes

\begin{tabular}{llll}
\hline & Control & HP & HC \\
\hline
\end{tabular}

Receptors number $\left(10^{9} / \mathrm{mg}\right.$ protein $)$
HAIR
$14.6 \pm 2.0^{\mathrm{A}}$
$9.9 \pm 3.4^{\mathrm{A}}$
$13.1 \pm 2.3$
LAIR
$2245 \pm 464$
$2661 \pm 518$
$2483 \pm 417$

Association constants (mol/1)
HAIR $\left({ }^{*} 10^{9}\right)$
$12.7 \pm 4.3^{\mathrm{A}}$
$9.9 \pm 2.0^{\mathbf{B}}$
$18.1 \pm 3.2^{\mathrm{AB}}$
LAIR $\left(* 10^{6}\right)$
$11.3 \pm 5.1$
$10.0+8.4$
$11.4 \pm 3.9$

Specific binding (\%)
$11.6 \pm 0.9^{\mathrm{A}}$
$9.2 \pm 1.6^{\mathrm{AB}}$
$12.9 \pm 1.9^{\mathrm{B}}$

Receptors number $\left(10^{9} / \mathrm{mg}\right.$ protein)

Brain membranes
HAIR
$12.9 \pm 2.0^{\mathrm{A}}$
$10.4 \pm 1.0^{\mathrm{A}}$
$12.3 \pm 1.8$
LAIR
$2361 \pm 365^{\mathrm{A}}$
$3205 \pm 278^{\mathrm{A}}$
$2716 \pm 434$

Association constants (mol/1)
HAIR $\left({ }^{*} 10^{9}\right)$
$3.2 \pm 0.6^{\mathrm{A}}$
$2.4 \pm 0.4^{\mathrm{AB}}$
$3.2 \pm 0.7^{\mathrm{B}}$
$\operatorname{LAIR}\left({ }^{*} 10^{6}\right)$
$10.3 \pm 3.8$
$8.5 \pm 6.7$
$8.4 \pm 6.3$

Specific binding $(\%)$
$6.9 \pm 0.9^{\mathrm{A}}$
$5.8 \pm 0.7^{\mathrm{AB}}$
$6.9 \pm 0.5^{\mathrm{B}}$

Values expressed as mean $\pm \mathrm{SD}$ for 5 animals. Values marked in row by this same letter are significantly different at $\mathbf{P}<0.01$ according to one-way analysis of variance and mutiple range test

\section{DISCUSSION}

Insulin is a well characterized hormone which influences protein, carbohydrate and lipid metabolism. Because of the important function, there exist some mechanisms which control its action. One of them is regulation of insulin output from pancreas by many important ingredients of food. On the other hand, there 
are evidences that not only insulin secretion but also its action on target tissues can be regulated (Dardevet et al., 1991; Okamoto et al., 1992). The last phenomenon can take place under condition that number of receptors and/or their affinity to the hormone are changeable or some post-receptor events can be influenced by intermediary metabolites or insulin itself. In our previous investigations we stated that present in a diet hormone-like substances, called phytooestrogens, change receptor content and reactivity of liver, muscle and blood red cells to insulin (Nogowski et al., 1991a, b). Results presented here indicate that changes in basic food ingredients can also influence on the receptor content and affinity of liver and brain to the hormone. The carbohydrate-rich diet caused some enhancement of specific insulin binding both in liver and brain membranes. This effect seems to be not a result of increased quantity of binding places but their enhanced affinity. Simultaneously, excess of protein in diet caused lowering of HAIR level and their affinity to insulin in investigated tissues. The phenomenon of food influence on receptors was reported by Okamoto et al. (1992), who observed that a lipid-rich diet ( $36 \%$ fat) diminished the autophosphorylation of muscle and liver insulin receptors on tyrosine residues and caused their resistance to insulin. However, the authors stated no changes in the insulin binding, receptor number or affinity constant. Their data suggest that a high-fat diet causes a post-receptor defect. In other studies Dardevet et al. (1991) stated that a high-protein food decreased number of high affinity receptors in liver of growing rats. On the other hand, fasting increases both the quantity of binding sites and specific binding (Almira and Reddy, 1979). Our experiments confirmed lowering of HAIR number in liver after protein-rich diet and - in addition - we noticed that this same effect was also revealed in brain. Moreover, some effects evoked by this kind of diet are opposite to that observed after excess of carbohydrates which enhance association constant in liver.

The direction of changes was, in general, the same in liver and brain, however the last organ seems to be less sensitive. Brain membrane high affinity receptors show lower affinity to insulin than liver ones. It can be a result of differences in structure of receptors originating from various tissues. The brain receptor is a bit smaller molecule and this distinction arises from differences in $\mathrm{N}$-linked glycosylation (Unger et al., 1991a; Gammeltoft et al., 1984). However, besides described differences in the characteristics of brain and liver membrane receptors, in the light of the present paper, it can be stated both their ability to changing in various circumstances and the regulatory effect of a diet on them. It seems to be very interesting especially referring to brain, which is usually considered not to be a target tissue for insulin. 


\section{CONSLUSIONS}

1. Food ingredients change insulin receptors content and affinity not only in main target organ - liver - but in brain, too.

2. Brain, however, is less sensitive to nutritional factors.

3. Excess of protein in a diet leads to diminishing of sensitivity of liver and brain to insulin, whereas carbohydrates evoke the opposite effect.

\section{REFERENCES}

Almira E.C., Reddy W.J., 1979. Effects of fasting on insulin binding to hepatocytes and liver plasma membranes from rats. Endocrinology 104, 205-211

Dardevet D., Manin M., Balage M., Sornet C., Grizard J., 1991. Influence of low- and high-protein diets on insulin-like growth factor-1 binding to skeletal muscle and liver in the growing rats. $\mathrm{Br}$. J. Nutr. 65, 47-60

De Lean A., Munson P.J., Rodbard D., 1978. Simultaneous analysis of families of sigmoidal curves: application to bioassay, radioligand assay, and physiological dose-response curves. Amer. J. Physiol. 235, E97-E102

Gammeltoft S., Kowalski A., Fehlmann M., van Obberghen E., 1984. Insulin receptors in rat brain: Insulin stimulates phosyphorylation of its receptor $\beta$-subunit. FEBS Lett. 172, 87-90

Havrankova J., Roth J., Brownstain M.J., 1978. Insulin receptors are widely distributed in the central nervous system of the rat. Nature 272, 827-829

Lawrence J.C., Guinovart J.J., Larner J., 1976. Activation of rat adipocite glycogen synthase by insulin. J. Biol. Chem. 252, 444450

Lewis A.McD., Kaye P.L., Lising R., Cameron R.D.A., 1992. Stimulation of protein synthesis and expansion of pig blastocysts by insulin in vitro. Reprod. Fert. Develop. 4, 119-123.

Lowry O.H., Rosenbroth W.J., Farr A.Z., Randall R.J., 1951. Protein measurement with the Folin phenol reagent. J. Biol. Chem. 193, 265-275

Maćkowiak P., 1990. Amino acid - induced insulin release from the perfused rat pancreas. The influence of phenylalanine and tyrosine. Acta physiol. pol. 41, 169-175

Munson P.J., Rodbard D., 1980. LIGAND: a versatile computerized approach for characterization of ligand-binding systems. Anal. Biochem. 107, 220-239

Nogowski L., Maćkowiak P., Nowak K.W., 1992a. The effect of $17 \beta$ oestradiol and coumestrol on rabbit erythrocyte insulin receptors. J. Anim. Physiol. Anim. Nutr. 67, 25-29

Nogowski L., Nowak K.W., Maćkowiak P., 1992 b. Effect of phytooestrogen - coumestrol and oestrone on some aspects of carbohydrate metabolism in ovariectomized female rats. Arch. Vet. pol. $32,79-84$

Okamoto M., Okamoto M., Kono S., Inoue G., Hayashi T., Kosaki A., Maeda I., Kubota M., Kuzya H., Imura H., 1992. Effects of a high-fat diet on insulin receptor kinase and the glucose transporter in rats. J. Nutr. Biochem. 3, 241-250

Scatchard G., 1949. The attractions of proteins for small molecules and irons. Ann. N. Y. Acad. Sci. 51, $660-672$

Susini C., Lavau M., Herzog J., 1979. Insulin effect in vivo on acetyl-coenzyme A carboxylase in adipose tissue of rats fed a low or a high-fat diet. Hormone Metab. Res. 11, 694-696

Steffens A.B., Flik F., Kuipers F., Lotter E.C., Luiten P.G.M., 1984. Hypothalamically-induced insulin release and its potentation during oral and intravenous glucose loads. Brain Res. 301, 351-361 
Unger J.W., Livingston J.N., Moss A.M., 1991a. Insulin receptors in the central nervous system: localization, signalling mechanisms and functional aspects. Prog. Neurobiol. 36, 343-362

Unger J.W., Moss A.M., Livingston J.N., 1991b. Immunochemical localization of insulin receptors and phosphotyrosine in the brain stem of the adult rat. Neuroscience $42,853-861$

\section{STRESZCZENIE}

Dieta wysokowęglowodanowa i wysokobiałkowa wplywają na receptory insulinowe wątroby i mózgu

Badano błonowe receptory insulinowe wątroby i mózgu szczurów żywionych paszą standardową (S), wysokowęglowodanową (HC) i wysokobiałkową (HP). Zarówno wątroba jak i mózg wykazują podobną tendencję do redukcji receptorów o wysokim powinowactwie, a także obniżania ich powinowactwa u zwierząt żywionych paszą HP. Dieta HC wydaje się wywierać działanie odwrotne. Zwierzęta mają prawie taką samą ilość receptorów jak w grupie kontrolnej, ale powinowactwo wiązania insuliny do blon wątrobowych - lecz nie mógzowych - jest podniesione. 